\title{
Impact of Organizational Justice Dimensions of Employees Performance in Higher
}

\section{Educational Context}

\author{
* Dr. Irfan Ullah Khan (Corresponding Author) \\ ** Mian Muhammad Saleem, Associate Professor \\ *** Dr. Muhammad Idris, Assistant Professor
}

\begin{abstract}
The study aimed to examine the influence of the organizational justice dimensions on the employees' performance by analyzing views of faculty members from higher educational institutions of Khyber Pakhtunkhwa (KP), Pakistan. Organizational justice from different dimensions has been widely explored in a different context however, limited research is available in the education context in KP, Pakistan. The study aimed to explore relationships between the organizational justice dimensions like the allocation of rewards/resources (distributive justice), impartiality in procedures (procedural justice), the fair interaction (interactional justice), and employees' performance. The "cross-sectional research design was used" to collect data from faculty members through a questionnaire and analyzed by using the statistical procedures. The results provide significant information about the effect of justice dimensions on employees' performance. Some recommendations have been extracted from results offered to the policymakers of higher institutions supported by some practical implications to the future researchers.
\end{abstract}

Keywords: Organizational Justice Dimensions, Employees Performance, Higher Education Introduction

In Pakistan, higher education is confronting growing competition due to the emergence of numerous higher institutions in the private sector. In response to this challenge, the higher institutions in the public sector have become more competitive in providing quality education and in meeting the demands of the stakeholders. In this connection, the higher education commission puts more pressure on both private and public higher institutions to ensure the global standards in teaching and research (Niazi \& Mace, 2006). For this purpose, the quality enhancement cells have been introduced by the higher education commission at each institution that aims at quality assurance. In this regard, the higher institutions are direly needed to develop effective human resource strategies and policies overwhelmed at "higher performances on part of the employees" and institutions (Thornton \& Audrey, 2008). These strategies and practices are mainly aimed at promoting fairness in decisions, procedures, allocation of resources, and interactions to achieve the desired tasks in terms of quality and performance.

The performance is a dynamic phenomenon concerning employees improve behavior and institutional sustainability. The phenomenon of performance is alone enough to meet the institutional desired standing and ranking in competitive situations. The employees' attitude is dependent upon different factors those which affect the employees' behavior and working potential positively or negatively (Bowles \& Cooper, 2009). In this linking, occupational stress, burnout, unfavorable environment, and unfair decisions are the factors that influence the employees' behavior and performance negatively (Devonish \& Greenidge, 2010). Conversely, commitment, motivation, environmental dynamism, adaptability, extraversion, and conscientiousness are dynamic factors that influence the employees' behavior positively (Noblet Lawler \& Rodwell, 2012). Among these

\footnotetext{
* Department of Public Administration, Gomal University, Dera Ismail Khan, Pakistan Email: drikmarwat@gmail.com

** Department of Law, Abdul Wali Khan University Mardan Email: miansaleem@awkum.edu.pk

*** Department of Education, Abdul Wali Khan University Mardan Email: midrees@awkum.edu.pk
} 
dynamic factors, the perception of employees about fairness in the procedures, distribution, and interactions are foremost in nurturing the employees' behavior overwhelmed at higher performance on the part of institutions and employees.

The organizational justice represents the fairness in institutional actions that is dynamic for inspiring the employees towards better performances. However, employees' positive attitudes and actual performance tends to decline when the "employees feel that they are not treated" equally in the institutions (Otto \& Mamatoglu, 2015). The employees who realize fair treatment in institutions regarding resources, procedures, and interactions are likely to produce better outcomes over innovative behavior and best performances (Saboor, Rehman \& Rehman, 2018). The fairness is also dynamic for the institutions in shaping the employees' attitude towards long-term strategic objectives of the institution overwhelmed at institutional better performance, health, and success. It is an accredited fact that fairness and cultural diversity affects the attitudes, behaviors, and emotion of the employees in institutions (Akrama, Jamal \& Hussaina, 2020). Organizational justice is also important for higher institutions in reforming employees' behavior and achieving the desired ranking in the contemporary competitive environment.

\section{Problem Statement}

The fairness perception from different dimensions is vital in determining the employees' performance. This study aimed to survey the impact of organizational justice dimensions (procedural, distributive and interactional) on employees' performance in the context of higher education institutions. The employees' perceptions are dynamic in defining their attitude and behavior towards the institutional tasks which ultimately influences their work behavior (performance) positively or otherwise.

\section{Objectives of Study}

$\checkmark \quad$ They examine the role of organizational justice dimensions in predicting the employees' performance.

$\checkmark \quad$ To examine the association between the organizational justice dimensions and employees' performance.

$\checkmark \quad$ To examine the influence of organizational justice dimensions on the employees' performance.

\section{Literature Review}

In the contemporary competitive era, it is a phenomenon of greeter importance that how organizations treat the workforces. In this connection, different researchers suggest that "organizations should serve as platforms" for workers instead of only workforces serving as human machines for organizations (Breu, Hemingway, Strathern \& Bridger, 2002). The logic behind this concept depends on the workforces' reaction to their treatment in the organizations (Cropanzano, Bowen \& Gilliland, 2007). In this connection, organizational justice gained continuous momentum during the past decades regarding various dynamic results like motivation and performance (Nasurdin \& Khuan, 2011). The organizational justice theme is to ensure equality at workplaces that are further grounded upon the equity theory that ensures the impartiality from different dimensions (Zhang, Lepine, Buckman \& Wei, 2014). In an institutional context, when employees feel that fairness from different magnitudes (procedures, distribution, and interaction) is ensured then the employees are likely to show their best performance and motivation toward institutional tasks (Saboor Rehman \& Rehman, 2018). Equally, when employees feel that there are discriminations in treating the employees at the workplace then they are likely to put less effort by showing the least efforts in achieving the institutional tasks.

\section{Organizational Justice}

Organizational justice is the upshot of equity theory that determines whether the resource distribution is fair on the part of the organization towards employees or otherwise. In this connection, fairness is measured from two fundamental dimensions likewise the cost (inputs) and rewards (outcomes) (Cropanzano et al., 2007). Consequently, fairness denotes that whether institutional outcomes are fairly distributed as per inputs (efforts) put by employees in attaining institutional outcomes or otherwise (Zynalpoor, Sheikhi \& Kamaly, 2010). The organizational justice is the vital phenomenon that pivots around the behavior of the employees wherein the fairness acts as a facilitator in shaping behavior positively while unfairness leads to undesirable consequences like lower commitment and performance (Tahseen \& Akhtar, 2015). The academics defined the organizational justice from three dimensions like procedural (fairness in the procedures and policies), distributive (fairness in the 
allocation of resources), and interactional (fairness in mutual interactions) (Akrama, Jamal \& Hussaina, 2020). The dimensions of fairness/justice are important in shaping the employees' attitudes and behavior toward particular objectives in the institutional context.

\section{Procedural Justice}

The organizational justice from the procedural dimension includes employee perception of the institutional procedures, mechanism, intents, and decisions in determining the outcomes. The "procedural justice has significant impact" on employees' behavior that is overwhelmed at higher employees' outcomes (Cropanzano, Bowen \& Gilliland, 2007). When the employees are satisfied with institutional procedures then they are expected to show their utmost dedication and efforts toward the attainment of the institutional tasks effectively. However, when employees feel that institutional procedures and decisions are biased then they are likely to show little interest in institutional objectives (Noblet, Lawler \& Rodwell, 2012). The procedural justice helps in defining institutional actions and decisions in fair and transparent procedures leading to advanced moral and ethical values (Saboor, Rehman \& Rehman, 2018). It further explains institutional procedures about the distribution of institutional outcomes (formal procedures and fair outcomes) ap per the efforts and potentials of the employees while putting forward their utmost performance in attaining their assigned responsibilities in the effective manners in the institutions.

\section{Distributive Justice}

The distributive dimension of organizational justice denotes the organizational decisions about the resources' allocation to employees in just and clear behaviors thereby keeping in view the dynamic issues like equity, need, and distribution (Aryee, Chen \& Budhwar, 2004). The employees may adjust the quantity and quality of their efforts when they observe and compare the ratio of their input/outcome is fair/unfair. Consequently, the employees' efforts and performance are dependent upon their perception of equal sharing in distribution (Devonish \& Greenidge, 2010). Distributive justice defines the institutional decisions about the processes behind the dispersion of outcomes, emphases upon fairness about the social and the economic consequences of the decision-making process (Thamna, Hossam \& Elanain, 2014). The equity theory explained the distributive justice with the notion that employees acquire the logic of the distributive fairness by equating the work outcomes that they gain from their work efforts with outcomes that they obtained by referent distribution (Saboor et al., 2018). In this connection, employee job contributions include factors like skills, knowledge, time, effort, cognitive resources, and performance.

\section{Interactional Justice}

The interactional measurement of organizational justice signifies the fair treatment of the employees at the workplace. This interaction is mainly concerned with the communication and information flow between employees and institution that regulates the employees' concerns about how the institution cares about the employees' needs and to what extent the institutions is sympathetic in understanding and pleasing these needs (Nowakowski \& Conlon, 2005). The fair and just interaction inspire the employees to show higher performances towards institutional long-term objectives (Holtz \& Harold, 2009). The fair interaction denotes the effective relationships between employees and institutions which has been supported by various researchers from the social exchange theory (Otto \& Mamatoglu, 2015). The interactional justice has a significant association with employees' performance as validated in different contexts (Benson \& Martin, 2017). The peer to peer relationship signifies the positive links between employees and institution based upon the fair decisions supported by mutual interaction (informational \& interpersonal) that is vital for the institutions to get the employees motivated and committed.

\section{Employees Performance}

The performance is the multi-dimensional concept which is the combination of various dynamic issues like contextual and task performance, job dedication, and interpersonal facilitation. In this connection, both the task and contextual performances are vital for the institutions in realizing desired standards (Armstrong \& Baron, 2005). The employees' performance is the effort that is beyond the job roles that further inspire the processes and tasks overwhelmed at shaping the psychological and social environment in institutions (Thomas \& Feldman, 2009). The performance is the outcome of the employees' efforts, dedication, and motivation that are vital for the institutions in realizing their strategic objectives. The performance of the employees is the building block for the institutions to 
sustain their prolonged competitiveness in the contemporary competitive environment (Asif \& Searcy, 2014). The employees are expected to show higher performances when they realize that the institutions are effective in managing the employees' genuine needs and desires (Ahmed \& Mostafa, 2017). The employees' performance is the most effective phenomenon for institutions in attaining their desired status and ranking.

\section{Organizational Justice \& Employees Performance}

Organizational justice is a significant predictor of employees' motivation, commitment, loyalty, wellbeing, and performance. The higher institutional performance is contingent upon mutual support and cooperation between employees and institutions (Armstrong \& Baron, 2005). The fair treatment of employees supported by fair decisions is dynamic for motivating the employees towards best performances. Similarly, the just and fair procedures are vital for the institution and employees in sharing their mutual interests as the fair procedures and processes inspire the employees towards higher values institutional tasks (Burton, Sablynski \& Sekiguchi, 2008). Likewise, the institutional fair decisions regarding the allocation of resources as per the efforts and potentials of the employees are also significant for institutions in attaining their desired standards and objectives (Arman, Latif \& Ali, 2014). Employees' performance and fairness perception are directly related to each other as the fairness perception motivates the employees for attaining the institutional tasks more effectively (Akrama, Jamal \& Hussaina, 2020). The fairness perception leads the employees towards innovative behavior where employees are more conscious in utilizing the institutional resources more effectively and efficiently.

Figure 1 Theoretical Framework

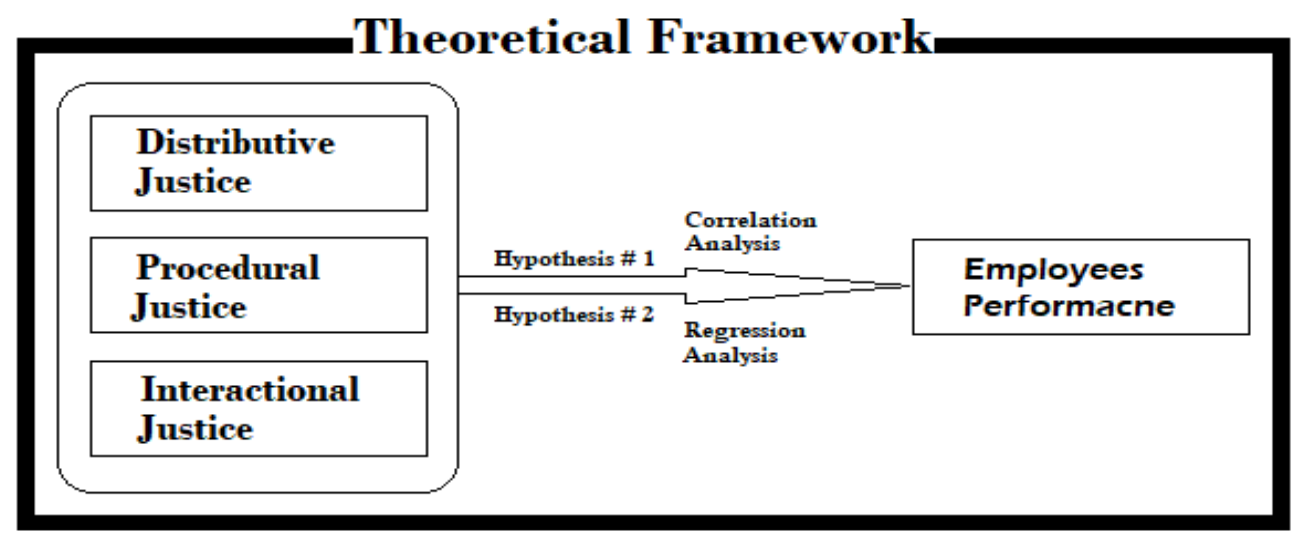

\section{Research Hypotheses}

$\mathbf{H}_{1}$ : The organizational justice dimensions are significantly and positively associated with the employees' performance.

$\mathbf{H}_{2}$ : The organizational justice dimensions have a positive and significant impact on the employees' performance.

\section{Research Methodology}

To explore the relationships among the organizational justice dimensions and employees' performance, the faculty members from higher education institutions were invited to fill the questionnaires. As, the entire population is not accessible or sometimes not necessary therefore, "convenient sampling technique was used to collect data from" respondents (Sekaran \& Bougie, 2009). Similarly, the study is based on exploring relationships between existing realties (organizational justice dimensions \& employees' performance) in the native environment by using statistical procedures to conclude, therefore, a positivist approach was applied to conduct research (Cooper \& Schindler, 2008). A sample of 356 was selected from the population (1740) via the statistical formula (Yamani, 1967). A total of 356 questionnaires were distributed wherein 322 were recollected. The organizational justice dimensions scale was adapted from the previous study (Al$\mathrm{Zu}$ 'bi, 2010) while the employees' performance scale was adopted from the previous study (Teseema \& Soeters, 2006). The descriptive and inferential design was used to examine relationships among research variables via correlation and regression. The reliability of the instrument was ensured through Cronbach Alpha.

Table 1 Reliability Statistics 


\begin{tabular}{clcc}
\hline SN & \multicolumn{1}{c}{ Research Variables } & Items & Cronbach Alpha \\
\hline 1 & Procedural Justice & 08 & .841 \\
2 & Distributive Justice & 08 & .873 \\
3 & Interactional Justice & 08 & .755 \\
4 & Employees Performance & 10 & .864 \\
5 & Questionnaire & 34 & .891 \\
\hline
\end{tabular}

The instrument was adopted from previous studies; thus, the cultural differences leads researchers to examine the reliability of the instrument that whether or not the instrument is reliable in the existing context or otherwise. The reliability (internal consistency) was examined through Cronbach Alpha wherein the minimum acceptable value (.6) in social sciences. However, the values for variables are above the threshold values like procedural justice (.841), distributive justice (.873), interactional justice (.755), performance (.864), and the overall questionnaire (.891). Consequently, from the results, it is evident that the instrument has acceptable/good internal consistency in terms of reliability among the variables of research.

\section{Results and Discussions}

The data analysis is that part of the research wherein results obtained through statistical procedures have been presented. The inferential research design was used to examine the relationships among research variables. Similarly, the results have been compared with the findings of existing studies to "make clear the position of current study". For this purpose, the correlation was used to examine association while regression was used to observe the variance in criterion variable due to predictor as offered by R2 (coefficient of determination) while Beta denotes the effects of predictors on the criterion variable of the study.

Table 2 Descriptive Statistics

\begin{tabular}{|c|c|c|c|c|c|}
\hline Variables & $\begin{array}{c}\mathrm{N} \\
\text { Statistic }\end{array}$ & $\begin{array}{l}\text { Minimum } \\
\text { Statistic }\end{array}$ & $\begin{array}{l}\text { Maximum } \\
\text { Statistic }\end{array}$ & $\begin{array}{c}\text { Mean } \\
\text { Statistic }\end{array}$ & $\begin{array}{c}\text { Std. Deviation } \\
\text { Statistic }\end{array}$ \\
\hline Procedural Justice & 322 & 2.64 & 6.87 & 4.9585 & 1.03090 \\
\hline Distributive Justice & 322 & 1.77 & 7.59 & 4.0602 & 1.05472 \\
\hline Interactional Justice & 322 & 1.44 & 6.76 & 4.3889 & 1.14261 \\
\hline Employees Performance & 322 & 1.77 & 7.02 & 4.3138 & 1.26455 \\
\hline \multicolumn{6}{|c|}{ Table 3 Skewness and Kurtosis } \\
\hline \multirow[t]{2}{*}{ Variables } & \multicolumn{3}{|c|}{ Skewness } & \multicolumn{2}{|c|}{ Kurtosis } \\
\hline & & istic & Std. Error & Statistic & Std. Error \\
\hline Procedural Justice & & 263 & .136 & -.542 & .271 \\
\hline Distributive Justice & & 94 & .136 & -.041 & .271 \\
\hline Interactional Justice & & 283 & .136 & -.023 & .271 \\
\hline Employees Performance & & 70 & 136 & -.396 & .271 \\
\hline
\end{tabular}

The descriptive statistics and normality have been offered in tables $(2 \& 3)$. It provides the data in describing the research variables (organizational justice dimensions) and the employees' performance. The descriptive table offered data about the responses rate of the respondents (maximum and minimum) along with the mean and the standard deviation which is satisfactory. However, the Skewness and Kurtosis provide the data about the normality of research variables. The previous studies show that skewness and kurtosis values need to be between -2 to +2 (Hair, Black, Babin \& Anderson, 2010), between +3 and -3 (Pallant, 2010) and between -7 to +7 (Bryne, 2010). In the present case, the values of "Skewness and Kurtosis" are within the threshold values as suggested by the researchers therefore, the variables in the construct have good normality and thus normal for further examination.

Table 4 Correlation Analysis $\left(\mathrm{H}_{1}\right)$

\begin{tabular}{clccc}
\hline Variables & \multicolumn{1}{c}{ Correlation } & 'rocedural JusticeDistributive Justice & $\begin{array}{c}\text { Interactional } \\
\text { Justice }\end{array}$ \\
\hline Employees Performance & Pearson Correlation & $.752^{* *}$ & $.816^{* *}$ & $.654^{* *}$ \\
& Sig. (2-tailed) & .000 & .000 & .000 \\
& $\mathrm{~N}$ & 322 & 322 & 322 \\
\hline
\end{tabular}

**. Correlation is significant at the 0.01 level (2-tailed).

The results of correlation show a positive and significant association among organizational justice dimensions (procedural, interactional \& distributive) and employee performance. The highest association (.816 \& .000) was found in between the distributive justice and employee performance 
preceded by $(.752 \& .000)$ between the employees' performance and procedural justice. The significant association (.654 \& .000) was found between employees' performance and interactional justices meaning that the faculty members in higher education context are more worried about distributive justice preceded by the procedural and interactional justices. From the results, the hypothesis about association is accepted. The results are in line to some extent with the previous results conducted in different contexts and thus the results have been validated (Lam, Schaubroeck \& Aryee, 2002; Devonish \& Greenidge, 2010; Noblet, Lawler \& Rodwell, 2012; Kalay \& Turkey, 2016; Saboor, Rehman \& Rehman, 2018).

Table 5 Regression Analysis (Model Summary) $\left(\mathrm{H}_{2}\right)$

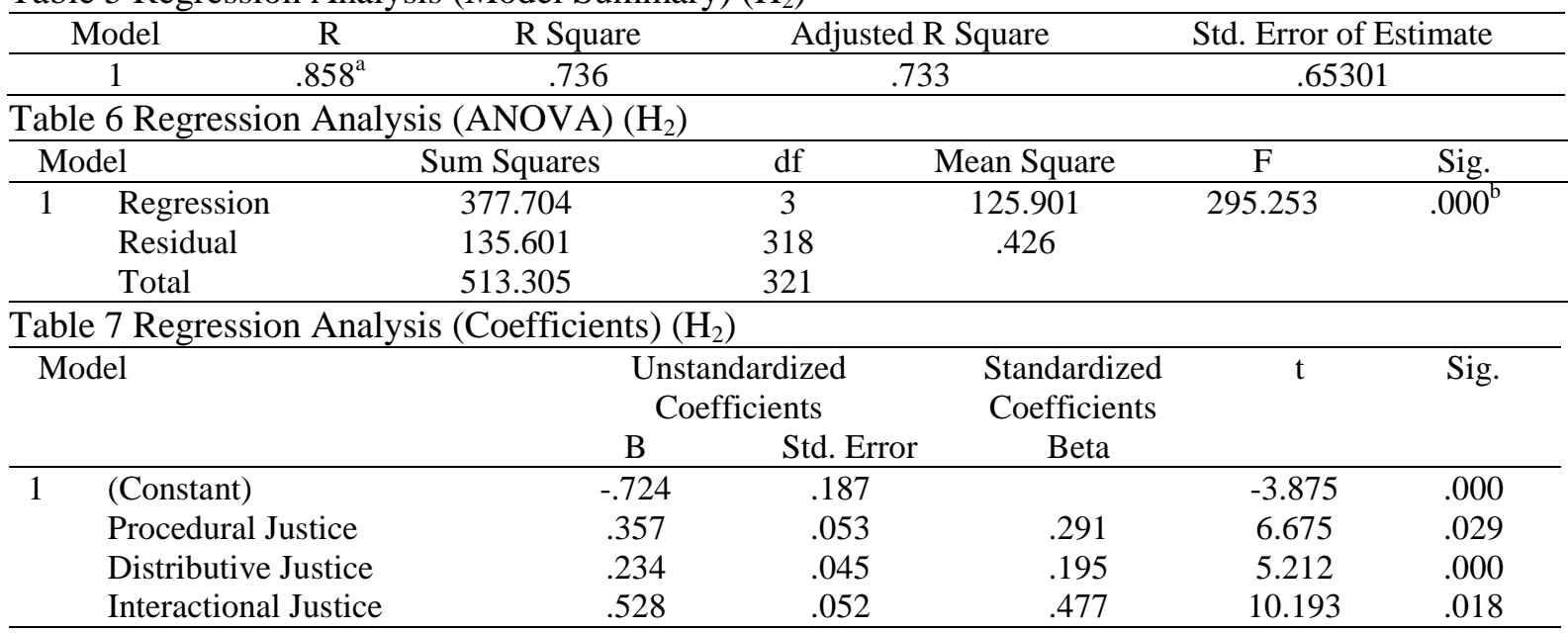

a. Predictors: (Constant): Distributive Justice, Procedural Justice, Interactional Justice

b. Dependent Variable: Employees Performance

The predictability of employees' performance through organizational justice dimensions was examined through hypothesis \# 2 by applying the regression. The results show that predictors (procedural, distributive and interactional) are responsible in bringing $73.6 \%$ variance in the employees' performance (criterion variable). The coefficient of regression shows that predictors have a positive and significant effect on employees' performance like procedural justice (.357 \& .029), distributive justice (.234 \& .000), and interactional justice (.528 \& .018) respectively. The results again show that distributive justice is more significant as compared to interactional and procedural justice which also supports the correlation results. The hypothesis \# 2 is thus accepted. The results are in line with the previous study results (Walumbwa, Cropanzano \& Hartnell, 2009; Ko \& Hur, 2014; Muhammad \& Shaheen, 2015; Khan, Shukor \& Ismail, 2016; Mehmood, Norulkamar \& Ahmad, 2016).

\section{Conclusion and Recommendations}

In higher education institutions, the employees are more concerned with certain dynamic factors wherein the fairness perception is more important that pivots around many other issues like commitment, motivation, and performance. The study was conducted in a higher educational context by examining the views of respondents about organizational justice dimensions and its impact on performance. The results reveal that among dimensions of organizational justice, distributive justice is more significant meaning that faculty are more concerned about the distribution of institutional resources in fair and transparent manners followed by procedural and interactional justices. The results further show the significant association was evident between "dimensions of organizational justice" and employee performance validated through the existing research studies. Therefore, it is concluded that fairness perception is critical for employees in shaping their attitude and behavior towards the attainment of institutional objectives more effectively. The fairness in institutional procedures, resource distribution, and impartial interactional is vital for the institutions in making positive behavioral changes in the employees' attitude leading to a higher level of performance.

\section{Recommendations}

Organizational justice is a strong predictor of decent and desired performances in the institutions. Thus, the management of institutions is required to put more emphasis on fairness 
to motivate employees towards better performances leading to higher institutional credibility and success.

$\checkmark \quad$ Distributive justice is more significant in the present study which shows that the faculty members are more concerned about the distribution of institutional resources. Thus, institutional management is required to ensure the resources distribution as per the efforts, potential, and performance of the employees.

$\checkmark \quad$ The procedural justice is also significant wherein the focus remained on the fair procedures and processes. Therefore, the institutions are required to ensure the fair procedures in satisfying the genuine needs of the employees to make them inspired towards higher performances.

$\checkmark \quad$ The interactional justice is also significant wherein the focus is given to fair and just relationships between employees and institutions. Therefore, the institutions are required to treat equally all the employees to yield their trust which in turn will inspire them to show higher commitment and performance.

\section{References}

Ahmed, M., \& Mostafa, S. (2017). High-performance HR practices, positive affect, and employee outcomes. Journal of Managerial Psychology, 32 (2), 163-176.

Akrama, T., Jamal, M., \& Hussaina, S. (2020). The impact of organizational justice on employee innovative work behavior: Mediating role of knowledge sharing. Journal of Innovation \& Knowledge, 5, 117-129

Al-Zu'bi, H. A. (2010). A study of the relationship between organizational justice and job satisfaction. International Journal of Business and Management, 5(12),102-109.

Arman, H., Latif, L. A., \& Ali, J. (2014). Organizational Justice as a predictor of self-perceived work performance: A perspective from Malaysian higher educational institutions. Mediterranean Journal of Social Sciences, 5 (23), 319-325.

Armstrong, M., \& Baron, A. (2005). Managing Performance: Performance Management in Action. London, Chartered Institute of Personnel and Development.

Aryee, S., Chen, Z. X., \& Budhwar, P. S. (2004). Exchange fairness and employee performance: an examination of the relationship between organizational politics and procedural justice. Organizational Behavior and Human Decision Processes, 94, 1-14.

Asif, M., \& Searcy, C. (2014). A composite index for measuring performance in higher education institutions. International Journal of Quality \& Reliability Management, 31 (9), 983-1001

Benson, T. H., \& Martin, L. (2017). The effect of inter-organizational justice perceptions on organizational citizenship behaviors in construction projects. International Journal of Project Management, 35, 95-106.

Bowles, D., \& Cooper, C. (2009). Employee morale: Driving performance in challenging times. Palgrave Macmillan. New York.

Breu, K., Hemingway, C.J., Strathern, M. and Bridger, D. (2002), "Workforce agility: the new employee strategy for the knowledge economy", Journal of Information Technology, Vol. 17 No. 1, pp. 21-31.

Burton, J. P., Sablynski, C. J., \& Sekiguchi, T. (2008). Linking justice, performance, and citizenship via leader-member exchange. Journal of Business and Psychology, 23 (1/2), 51-61.

Byrne, B. M. (2010). Multivariate applications series. Structural equation modeling with AMOS: Basic concepts, applications, and programming (2nd ed.). Routledge/ Taylor \& Francis Group.

Cooper, D., \& Schindler, P. (2008). The Business Research Methods, USA, McGraw-Hill Companies, Inc.

Cropanzano, R., Bowen, D. E., \& Gilliland, S.W. (2007). The management of organizational justice. Academy of Management Perspectives, 21(4), $34-48$

Devonish, D., \& Greenidge, D. (2010). The effect of organizational justice on contextual performance, the counterproductive work behaviors, and the task performance: Investigating the moderating role of ability-based emotional intelligence. International Journal of Selection and Assessment, 18, 1, 76-86. 
Hair, J., Black, W., Babin, B. \& Anderson, R. (2010). Multivariate data analysis: A global perspective, 7th edition, US, Pearson Prentice Hall.

Holtz, B. C., \& Harold, C. M. (2009). Fair today, fair tomorrow? A longitudinal investigation of overall justice perceptions. Journal of Applied Psychology, 94 (5), 1185-1199.

Kalay, F., \& Turkey, V. (2016). The Impact of Organizational Justice on Employee Performance: A Survey in Turkey and Turkish Context. International Journal of Human Resource Studies, 6 (1), 1-20.

Khan, Q., Shukor, A., \& Ismail, S. S. (2016). Career Success and Organizational Justice as the Potential Predictors of Perceived University Performance: A Study from Public Sector Universities of Pakistan. International Journal of Economics \& Management Sciences, 5:4, 16.

Ko, J., \& Hur, S. (2014). The impacts of employee benefits, procedural justice, and managerial trustworthiness on work attitudes: Integrated understanding based on social exchange theory. Public Administration Review, 74 (2), 176-187.

Lam, S. K., Schaubroeck, J., \& Aryee, S. (2002). Relationship between organizational justice and employee work outcomes: a cross-national study. Journal of Organizational Behavior, 23, 118.

Mehmood, N., Norulkamar, U., \& Ahmad, U. (2016). Organizational justice and employee performance: Evidence from Higher Education Sector in Pakistan. Journal Kemanusiaan, 25 (2), 48-56.

Muhammad, S. H., \& Shaheen, M. A. (2015). Impact of organizational justice on job performance in libraries mediating role of leader-member exchange relationship. Library Management, 36 $(1 / 2), 70-85$.

Nasurdin, A. M., \& Khuan, S. L. (2011). Organizational justice, age, and performance connection in Malaysia. International Journal of Commerce and Management, 21(3), 273-290.

Niazi, H., \& Mace, J. (2006). The contribution of the private sector to higher education in Pakistan with particular reference to efficiency and equity. Bulletin of Education \& Research, 28 (2), $17-42$.

Noblet, A., Lawler, S., \& Rodwell, J. (2012). Using job strain and organizational justice models to predict multiple forms of employee performance behaviors among Australian policing personnel. The International Journal of Human Resource Management, 23 (14), 3009-3026.

Nowakowski, M. M., \& Conlon, D. E. (2005). Organizational justice: Looking back, looking forward. The International Journal of Conflict Management, 16, 4-29.

Otto, K., \& Mamatoglu, N. (2015). Why does interactional justice promote organizational loyalty, job performance, and prevent mental impairment? The role of social support and social stressors. The Journal of Psychology, 149 (2), 193-218.

Pallant, J. (2010). SPSS survival manual: A step by step guide to data analysis using the SPSS program. 4th Edition, McGraw Hill, New York.

Saboor, A., Rehman, M., \& Rehman, S. (2018). Organizational justice and employee contextual performance: The moderating effect of organizational respect. Pakistan Business Review (Jan, 2018), 995-1011.

Sekaran, U. \& Bougie, R. (2011). The Research methods for business: A skill-building approach. 5th ed., London, John Wily and Sons Ltd.

Tahseen, N., \& Akhtar, M. S. (2015). Effect of Organizational Justice on Faculty Trust in University Education Faculties. Journal of Research and Reflections in Education, 9 (1), 26 -41.

Tessema, M. and Soeters, J. (2006). Challenges and prospects of HRM in developing countries: testing the HRM-performance link in Eritrean civil service. International Journal of Human Resource Management. 17(1), 86-105.

Thamna, S., \& Elanain, H. A. (2014). Procedural and distributive justice as mediators of the relationship between interactional justice and work outcomes. The Journal of Applied Business Research, 30 (4).

Thomas, W. H., \& Feldman, C. D. (2009). How broadly does education contribute to job performance? Personnel Psychology, 62, 89-134. 
Thornton, C. H., \& Audrey, J. (2008). The role of culture in institutional and individual approaches to civic responsibility at research universities. The Journal of Higher Education, 79 (2), 160-182.

Walumbwa, F. O., Cropanzano, R., \& Hartnell, C. A. (2009). Organizational justice, voluntary learning behavior, and job performance: A test of the mediating effects of identification and leader-member exchange. Journal of Organizational Behavior, 30 (8), 1103-1126.

Yamani, T. (1967). Statistics: An Introductory Analysis, 2nd Edition, New York: Harper and Row.

Zhang, Y., Lepine, J. A., Buckman, B. R., \& Wei, F. (2014). It's not fair or is it? The role of justice and leadership in explaining work stressor-job performance relationships. Academy of Management Journal. 57(3), 675-697.

Zynalpoor, S., \& Kamaly, M. (2010). Correlation with organizational justice and job satisfaction among teachers of school in Bandar Abbas. Journal of Behavioral \& Social, 5 (2), 34-51. 